\title{
Combining yield, earliness and plant height in a single genotype: a proposal for breeding in grain sorghum (Sorghum bicolor L.)
}

\section{Combinación del rendimiento, precocidad y altura de la planta en un solo genotipo: una propuesta para mejoramiento en sorgo de grano (Sorghum bicolor L.)}

\begin{abstract}
Larissa Pereira Ribeiro ${ }^{1}$, Flávio Dessaune Tardin ${ }^{2}$, Cícero Beserra de Menezes ${ }^{2}$, Aisy Botega Baldoni ${ }^{3}$, Paulo Eduardo Teodoro ${ }^{4 *}$, Leonardo Lopes Bhering ${ }^{1}$
\end{abstract}

Originales: Recepción: 06/05/2019 - Aceptación: 13/08/2020

\begin{abstract}
Grain sorghum production has expanded during the off-season when rainfall oscillates and becomes insufficient. Aiming to obtain better adapted cultivars, breeding programs have sought new combinations of hybrids with earliness, high grain yield, and ideal plant height for harvesting. This study aimed to estimate de combining ability of grain sorghum lines, proposing a breeding strategy, to identify hybrids gathering high yield, earliness, and desired plant height. Thirty-six hybrids from crosses of 12 lines were evaluated at two sites in the Brazilian region known as Cerrado biome. The evaluated traits were: days to flowering, plant height, and grain yield. For the diallel analysis, Method 4 of Griffing adapted to partial diallel was adopted. By combining ability analysis, we identified promising lines to be used as parents to obtain more yielding, early, and ideal height hybrids. The findings allowed us to propose a breeding strategy, in which complex crosses should be performed to gather favorable alleles in new restorer and male-sterile lines. The hybrids 7, 9, 19, and 22 are the most suitable for growing in the evaluated sites.
\end{abstract}

\section{Keywords}

combining ability • diallel • hybrids • male sterility • Sorghum bicolor L.

1 Federal University of Mato Grosso do Sul. Department of Crop Science. Rodovia MS 306. Km 105. CEP 79560-000. Chapadão do Sul. MS. Brazil.

2 Brazilian Agricultural Research Corporation (Embrapa) Maize and Sorghum. Rodovia MG 424. Km 45. CEP 35701-970. Sete Lagoas. MG. Brazil.

3 Brazilian Agricultural Research Corporation (Embrapa) Agrossilvipastoril. Rodovia dos Pioneiros MT 222. Km 2,5. CEP 78550-970. Sinop. MT. Brazil.

4 Federal University of Viçosa. Laboratory of Biometrics. Av. Peter Henry Rolfs, s/n. CEP 36570-900.Viçosa. MG. Brazil.*eduteodoro@hotmail.com 


\section{RESUMEN}

El cultivo de sorgo granífero se ha expandido durante la temporada baja, cuando la lluvia es oscilante e insuficiente. Para obtener cultivares mejor adaptados a estas condiciones, los programas de mejoramiento han buscado nuevas combinaciones de híbridos con precocidad, alto rendimiento de grano y altura ideal de la planta para la cosecha. Este estudio tuvo como objetivo estimar la capacidad de combinación de líneas de sorgo granífero, con el objetivo de proponer una estrategia de mejoramiento e identificar híbridos con alto rendimiento, precocidad y altura de plantas adecuadas para la cosecha. Treinta y seis híbridos obtenidos del cruzamiento entre 12 líneas fueron evaluados en dos sitios en la región brasilera denominada Bioma Cerrado. Los caracteres evaluados fueron: días hasta la floración, altura de la planta y el rendimiento de grano. Para el análisis del dialelo, se adoptó el Método 4 de Griffing adaptado al dialelo parcial. Por medio del análisis de capacidad de combinación, identificamos líneas promisorias para ser usadas como parentales con el fin de obtener híbridos de mayor rendimiento, precocidad y altura ideal. Los resultados nos permitieron proponer una estrategia de mejoramiento, donde cruzamientos complejos deben ser realizados para reunir alelos favorables para los caracteres en nuevas líneas restauradoras y macho estériles. Los híbridos 7, 9, 19 y 22 son los más adecuados para el cultivo en los sitios evaluados.

\section{Palabras clave}

capacidad combinatoria $\bullet$ dialelo $\bullet$ híbridos $\bullet$ macho esterilidad $\bullet$ Sorghum bicolor L.

\section{INTRODUCTION}

Grain sorghum [Sorghum bicolor (L.) Moench] is the fifth most cultivated cereal in the world, being a critical caloric source for human feeding in developing countries and in feed formulation for poultry, pigs, and cattle. One of the significant advantages of this crop is its high photosynthetic efficiency and high tolerance to abiotic stresses, especially to drought $(1,2,3,18)$. Grain sorghum tolerates and avoids drought better than many other cereal crops, like wheat and maize (1).

Drought tolerance makes sorghum especially important in arid and semi-arid regions of the world, such as Northeast Africa, India, and the plains of the southern United States (15). In Brazil, grain sorghum growing during the off-season has shown significant expansion in several agricultural regions, mainly in the Cerrado biome (20). At the time of grain sorghum sowing, in addition to temperature and luminosity factors, the volume and frequency of rainfall tend to oscillate and be insufficient, reducing the probability of adequate water supply for most crops. Aiming to have better adapted cultivars to these conditions, grain sorghum breeding programs have sought new combinations of hybrids with earliness, high grain yield, and ideal plant height for harvesting $(10,14,20)$.

One of the crucial decisions in breeding programs is choosing the populations to be used, since it is in these populations that the favorable alleles for the traits of interest should be concentrated, allowing the obtention of superior hybrids $(11,16)$. Diallel analyses are crucial for deciding how to form the base population, enabling the choice of promising parents based on estimates of combining ability. Furthermore, the analysis of diallel crosses contributes to understanding the genetic effects involved in the trait determination $(5,9)$. Therefore, the study of combining ability provides essential information for breeding program planning.

The objectives of this study were: i) to estimate the combining ability of grain sorghum lines, aiming at proposing a breeding strategy for developing new male-sterile and fertility restorer lines with potential for obtaining superior hybrids for the traits of interest, and ii) to identify hybrids that meet high yield, earliness and adequate height for harvesting in Cerrado biome. 


\section{MATERIAL AND METHODS}

\section{Field experiments}

Thirty-six grain sorghum hybrids were assessed in experiments during the $2011 / 2012$ harvest at two sites in the Brazilian Cerrado region. The experiments were carried out at Embrapa Agrossilvipastoril, in the municipality of Sinop-MT, and at Embrapa Maize and Sorghum, municipality of Sete Lagoas-MG. The climatic characteristics of the sites are shown in table 1.

Table 1. Soil and climatic characteristics of the evaluated sites.

Tabla 1. Características del suelo y clima de los sitios evaluados.

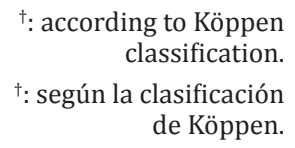
classification.

†: según la clasificación de Köppen.

\begin{tabular}{|c|c|c|c|c|c|}
\hline $\begin{array}{l}\text { Altitude } \\
\text { (m) }\end{array}$ & $\begin{array}{l}\text { Latitude } \\
\text { (S) }\end{array}$ & $\begin{array}{l}\text { Longitude } \\
\text { (W) }\end{array}$ & $\begin{array}{c}\text { Annual } \\
\text { rainfall }(\mathrm{mm})\end{array}$ & $\begin{array}{c}\text { Average } \\
\text { annual } \\
\text { temperature } \\
\left({ }^{\circ} \mathrm{C}\right)\end{array}$ & Climate $^{\dagger}$ \\
\hline 370 & $11^{\circ} 51^{\prime} 43^{\prime \prime}$ & $-55^{\circ} 36^{\prime} 45^{\prime \prime}$ & 2250 & 25 & Aw \\
\hline as-MG & $19^{\circ} 27^{\prime} 57^{\prime \prime}$ & $44^{\circ} 14^{\prime} 48^{\prime}$ & 1403 & 23 & Aw \\
\hline
\end{tabular}

For conducting these experiments, it was used 12 grain sorghum lines (six A lines: F1-A, F2-A, F3-A, F4-A, F5-A E F6-A; and six R lines: M1, M2, M3, M4, M5 e M6) from the sorghum breeding program of the Embrapa Maize and Sorghum, divided into two groups (I and II) according to the presence or absence of cytoplasmic-genetic male sterility. Group I was composed of six fertility restorative lines (R lines), i.e., fertile males. Group II was composed of six male-sterile lines (A lines), used as females (table 2).

Table 2. Source and code of the 36 hybrids from the cross between 12 sorghum lines, evaluated in Sinop-MT and Sete Lagoas-MG.

Tabla 2. Fuente y código de los 36 híbridos del cruzamiento entre 12 líneas de sorgo, evaluados en Sinop-MT y Sete Lagoas-MG.

\begin{tabular}{|c|c|c|c|c|c|c|c|}
\hline \multirow{2}{*}{ Source } & \multicolumn{3}{|c|}{ Code } & \multirow{3}{*}{ Source } & \multicolumn{3}{c|}{ Code } \\
\cline { 2 - 4 } \cline { 6 - 7 } & Hybrid & R Line & A Line & & Hybrid & R Line & A Line \\
\hline $1173-015$ & 1 & 1 & 1 & $1173-375$ & 19 & 4 & 1 \\
\hline $1173-001$ & 2 & 1 & 2 & $1173-361$ & 20 & 4 & 2 \\
\hline $1173-003$ & 3 & 1 & 3 & $1173-363$ & 21 & 4 & 3 \\
\hline $1173-013$ & 4 & 1 & 4 & $1173-373$ & 22 & 4 & 4 \\
\hline $1173-049$ & 5 & 1 & 5 & $1173-409$ & 23 & 4 & 5 \\
\hline $1173-051$ & 6 & 1 & 6 & $1173-411$ & 24 & 4 & 6 \\
\hline $1173-135$ & 7 & 2 & 1 & $1173-615$ & 25 & 5 & 1 \\
\hline $1173-121$ & 8 & 2 & 2 & $1173-601$ & 26 & 5 & 2 \\
\hline $1173-123$ & 9 & 2 & 3 & $1173-603$ & 27 & 5 & 3 \\
\hline $1173-133$ & 10 & 2 & 4 & $1173-613$ & 28 & 5 & 4 \\
\hline $1173-169$ & 11 & 2 & 5 & $1173-649$ & 29 & 5 & 5 \\
\hline $1173-171$ & 12 & 2 & 6 & $1173-651$ & 30 & 5 & 6 \\
\hline $1173-255$ & 13 & 3 & 1 & $1173-735$ & 31 & 6 & 1 \\
\hline $1173-241$ & 14 & 3 & 2 & $1173-721$ & 32 & 6 & 2 \\
\hline $1173-243$ & 15 & 3 & 3 & $1173-723$ & 33 & 6 & 3 \\
\hline $1173-253$ & 16 & 3 & 4 & $1173-733$ & 34 & 6 & 4 \\
\hline $1173-289$ & 17 & 3 & 5 & $1173-769$ & 35 & 6 & 5 \\
\hline $1173-291$ & 18 & 3 & 6 & $1173-771$ & 36 & 6 & 6 \\
\hline
\end{tabular}

The crosses for obtaining hybrids were conducted manually and controlled according to the model of partial diallel crosses between the groups, in which the six females of Group II were crossed with the six males of Group I, obtaining 36 hybrids. The sowing of the female lines was carried out ten days after the sowing of the male lines, in order to coincide with the flowering time of male lines. Cross rows were composed of 50 plants, distributed in five meters, and spaced in 0.7 meters. 
The sowing of the female and male lines was performed alternately in the field, where each female line was sown six times and alternating with the six males, making it possible to perform the crosses according to the partial diallel. After flowering, panicles of the parents were adequately protected with a paper bag, and crosses were performed according to the maturation of male and female reproductive systems. Manual pollinations consisted of the collection of pollen from male lines (Group I) using a paper bag for cross, followed by the pollen melt on stigmas of male-sterile lines (Group II). Crosses were performed in the morning, when the pollen grains were more abundant and the stigmas receptive.

The 36 hybrids from the crosses between the 12 sorghum lines were evaluated in experiments under rainfed conditions, with sowing performed on March 10, 2012. At 15 days after the seedling emergence, thinning was carried out for maintaining a population of 180,000 plants ha-1. The experimental design was a randomized complete block with two replicates. Each plot was composed of two rows of five meters spaced $0.50 \mathrm{~m}$ between them. Seed and cover fertilization were carried out based on chemical soil analysis, and cultural and phytosanitary treatments occurred according to the needs of the crop.

The evaluated traits were: days to flowering (DF), measured by counting the days from sowing to flowering $50 \%$ of the plants belonging to the plot area; plant height (PH), measured in meters, from the neck of the plant to the tip of the panicle; and grain yield (GY), corrected to $13 \%$ moisture and extrapolated to t ha- ${ }^{-1}$.

\section{Genetic-statistical analysis}

Initially, a joint analysis of variance was performed according to the statistical model described below:

$$
Y_{i j k}=\mu+B / E_{j k}+G_{i}+E_{j}+G x_{i j}+e_{i j k}
$$

where:

$\mathrm{Y}_{\mathrm{ijk}}=$ the observation in the k-th block, evaluated in the $\mathrm{i}$-th genotype and $\mathrm{j}$-th environment

$\mu \quad=$ the overall mean of the experiments

$B / E_{j k}=$ the effect of $k$ block within the $j$ environment

$\mathrm{G}_{\mathrm{i}} \quad$ = the effect of the $\mathrm{i}$-th genotype considered as fixed

$E_{j}=$ the effect of the $j$-th environment considered as random

$\mathrm{GxE}_{\mathrm{ij}}=$ the random effect of the interaction between i genotype and $\mathrm{j}$ environment

$\mathrm{e}_{\mathrm{ijk}}=$ the random error associated with observation $Y_{\mathrm{ijk}}$

Subsequently, the effect of genotypes and G x A interaction was unfolded at each site according to the partial diallel structure. Method 4 of Griffing (1956) adapted to partial diallel was adopted, which estimates the general (GCA) and specific (SCA) combining ability in partial diallel involving only $\mathrm{F}_{1} \mathrm{~s}$ hybrids, according to the model below:

$$
Y_{i j}=\mu+g_{i}+g_{j}+s_{i j}+e_{i j}
$$

where:

$\mathrm{Y}_{\mathrm{ij}}=$ the mean of the cross between the $\mathrm{i}$-th line of Group I and the $\mathrm{j}$-th line of Group II

$\mu=$ the overall mean of the diallel; $g_{i}$ is the general combining ability of the $i$-th line of Group I

$\mathrm{g}_{\mathrm{j}}=$ the general combining ability of the $\mathrm{j}$-th line of Group II

$s_{i j}=$ the specific combining ability of the lines of the Groups I and II

$e_{i j}=$ the experimental error

The GCA estimates of each group of lines and SCA estimates were plotted on a graph where the axes corresponded to the two sites analyzed. Subsequently, a mean clustering (overall and across sites) of the 36 crosses was performed by the Scott-Knott test (1974). All statistical analyses were performed with the Genes software (5) and followed the procedures recommended by Cruz et al. (2012). 


\section{RESULTS}

\section{Combining ability of grain sorghum lines}

The joint diallel analysis is shown in table 3 . The hybrid effect was significant for all traits evaluated. For GCA effects for R lines of the Group I (GCA I), there was significant only for plant height. Regarding the GCA for A lines of Group II (GCA II), there were significant effects for days to flowering and plant height. There was a significant SCA effect only for plant height. The GCA mean squares were higher than the SCA mean squares for all traits.

Table 3. Joint analysis of variance with the sources of variation and their respective mean squares, regarding a partial diallel analysis composed of 36 hybrids of grain sorghum from the cross among six male lines (R lines - Group I) and six male-sterile lines (A lines - Group

II) for the traits days to flowering, plant height $(\mathrm{m})$ and grain yield $\left(\mathrm{t} \mathrm{ha}^{-1}\right)$ evaluated at Sinop-MT and Sete Lagoas-MG.

Tabla 3. Análisis conjunto de la varianza con las fuentes de variación y sus respectivos cuadrados medios, con respecto a un análisis dialélico parcial compuesto de 36 híbridos de sorgo de grano del cruzamiento entre seis líneas masculinas (líneas R - Grupo I) y seis líneas masculinas-estériles (líneas A - Grupo II) para los caracteres días a floración, altura de planta $(\mathrm{m})$ y rendimiento de grano $\left(\mathrm{t} \mathrm{ha}^{-1}\right)$ evaluados en Sinop-MT y Sete Lagoas-MG.

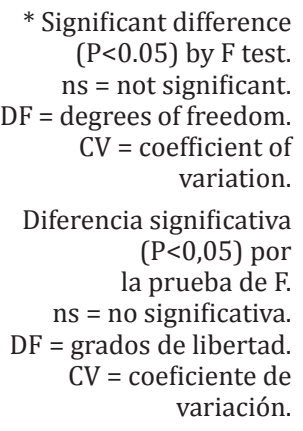
variación.

\begin{tabular}{|c|c|c|c|c|}
\hline \multirow{2}{*}{ Source of variation } & \multirow{2}{*}{ DF } & \multicolumn{3}{|c|}{ Mean Squares } \\
\cline { 3 - 5 } & & Days to flowering & Plant height & Grain yield \\
\hline Hybrids (H) & 35 & $37.7831^{*}$ & $0.1225^{*}$ & $2.3060^{*}$ \\
\hline GCA I - R lines & 5 & $88.9903^{\text {ns }}$ & $0.3032^{*}$ & $8.1720^{\text {ns }}$ \\
\hline GCA II - A lines & 5 & $87.6736^{*}$ & $0.3184^{*}$ & $3.6477^{\text {ns }}$ \\
\hline SCA & 25 & $17.5636^{\text {ns }}$ & $0.0472^{*}$ & $0.8644^{\text {ns }}$ \\
\hline Sites (E) & 1 & $6307.0069^{*}$ & $1.0438^{*}$ & $19.3453^{*}$ \\
\hline H x E & 35 & $20.6355^{*}$ & $0.0162^{*}$ & $1.1901^{*}$ \\
\hline GCA I x E & 5 & $19.4569^{*}$ & $0.0530^{*}$ & $2.3678^{*}$ \\
\hline GCA II x E & 5 & $17.3403^{*}$ & $0.0094^{\text {ns }}$ & $2.9838^{*}$ \\
\hline SCA x E & 25 & $21.5303^{*}$ & $0.0102^{\text {ns }}$ & $0.5959^{\text {ns }}$ \\
\hline Error & 70 & 2.4046 & 0.0077 & 0.4230 \\
\hline Mean & & 66.92 & 1.44 & 2.38 \\
\hline CV $(\%)$ & & 2.31 & 6.07 & 27.26 \\
\hline
\end{tabular}

The hybrid and site interaction ( $\mathrm{H} \times \mathrm{E}$ or $\mathrm{G} \times \mathrm{E}$ ) was significant for all evaluated traits, reflecting on significant GCA I x E interaction for all traits and significant GCA II x E for days to flowering and grain yield. However, the SCA x E interaction was significant only for days to flowering. The coefficient of variation (CV) was lower than $10 \%$ for days to flowering and plant height and lower than 30\% for grain yield.

Significant GCA x E interaction for days to flowering was represented in figure 1 (page 16). The M5 line presented a negative GCA estimate at the two sites. This contributed to the low means of the hybrids $(25,26,27,28,29$, and 30$)$ that had this line as male parent in both sites (table 4, page 17). The F1-A, F3-A and F4-A lines presented the lowest GCA estimates in both sites and also contributed to a decreased mean of the hybrids $(1,3,4,7,9,10,13,15$, $16,19,21,22,25,27,28,31,33$ and 34 ) for this trait in both sites.

Despite there was no significant interaction between GCA II x E for plant height, it was chosen to make a biplot graph with the GCA estimates for R and A lines at the two sites evaluated (figure 1, page 16). The M2 line stands out among the restorer lines of Group I by having the lowest GCA estimates at Sinop and Sete Lagoas, contributing to favorable alleles for decreasing plant height at these sites, except for the hybrid 10 at Sete Lagoas. Among the male-sterile lines, those with the lowest GCA estimates were F6-A and F5-A, both at Sinop and Sete Lagoas. These lines generated smaller plants at both sites, except the hybrids 5, 23, and 30, which were allocated to the highest mean Group at Sete Lagoas. 




Sete Lagoas



\section{Sete Lagoas}

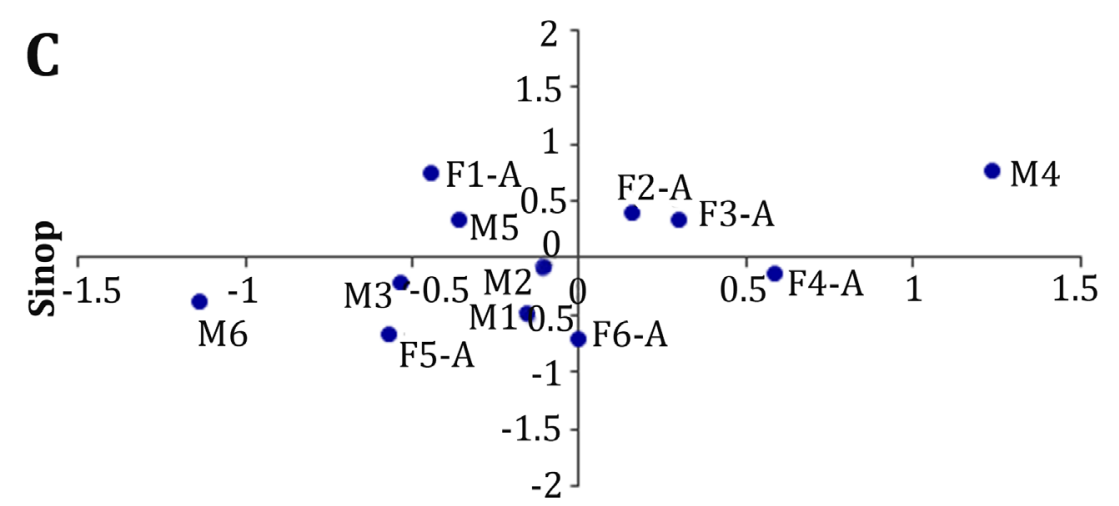

Sete Lagoas

Figure. 1. Estimates of general combining ability (GCA) for days to flowering (A), plant height (B) and grain yield (C) evaluated in 12 grain sorghum lines grown at Sinop-MT and Sete Lagoas-MG.

Figura 1. Estimaciones de capacidad general de combinación (CGC) para los caracteres días a floración (A), altura de planta (B) y rendimiento de grano (C) evaluados en 12 líneas de sorgo de grano cultivados en Sinop-MT y Sete Lagoas-MG. 
Table 4. Means clustering for the traits days to flowering, plant height ( $\mathrm{m}$ ) and grain yield $\left(\mathrm{t} \mathrm{ha}{ }^{-1}\right.$ ) evaluated in 36 grain sorghum hybrids grown at Sinop-MT and Sete Lagoas-MG.

Tabla 4. Agrupación de medias para los caracteres días a floración, altura de planta (m) y rendimiento de grano ( $\mathrm{t} \mathrm{ha}^{-1}$ ) evaluados en 36 híbridos de sorgo de grano cultivados en Sinop-MT y Sete Lagoas-MG.

Mean groups followed by the same letters in the same column do not differ by the Scott-Knott test at 0.05 significance. Grupos de media seguidos por las mismas letras en la misma columna no difieren por la prueba de Scott-Knott a 0,05 de significación.

\begin{tabular}{|c|c|c|c|c|c|c|c|}
\hline \multirow{2}{*}{$\begin{array}{l}\text { Parents } \\
0^{2} \times 9\end{array}$} & \multirow{2}{*}{ Hybrids } & \multicolumn{2}{|c|}{ Days to flowering } & \multicolumn{2}{|c|}{ Plant height } & \multicolumn{2}{|c|}{ Grain yield } \\
\hline & & Sinop & Sete Lagoas & Sinop & Sete Lagoas & Sinop & Sete Lagoas \\
\hline M1 x F1-A & 1 & $59.5 \mathrm{c}$ & $73.5 \mathrm{c}$ & $1.50 \mathrm{c}$ & $1.23 \mathrm{~b}$ & $2.56 \mathrm{~b}$ & $1.71 \mathrm{~b}$ \\
\hline M1 x F2-A & 2 & $60.0 \mathrm{c}$ & $75.5 \mathrm{~b}$ & $1.49 \mathrm{c}$ & $1.22 \mathrm{~b}$ & $2.52 \mathrm{~b}$ & $1.40 \mathrm{~b}$ \\
\hline M1 x F3-A & 3 & $61.0 \mathrm{c}$ & $73.5 \mathrm{c}$ & $1.77 \mathrm{a}$ & $1.58 \mathrm{a}$ & $3.62 \mathrm{a}$ & $2.67 \mathrm{a}$ \\
\hline M1 x F4-A & 4 & $59.0 \mathrm{c}$ & $73.0 \mathrm{c}$ & $1.45 \mathrm{c}$ & $1.24 \mathrm{~b}$ & $2.50 \mathrm{~b}$ & $1.56 \mathrm{~b}$ \\
\hline M1 x F5-A & 5 & $66.0 \mathrm{a}$ & $74.0 \mathrm{c}$ & $1.61 \mathrm{~b}$ & $1.39 \mathrm{a}$ & $1.73 \mathrm{~b}$ & $0.90 \mathrm{~b}$ \\
\hline M1 x F6-A & 6 & $63.5 \mathrm{~b}$ & $83.0 \mathrm{a}$ & $1.37 \mathrm{c}$ & $1.19 \mathrm{~b}$ & $2.61 \mathrm{~b}$ & $1.08 \mathrm{~b}$ \\
\hline M2 x F1-A & 7 & $60.0 \mathrm{c}$ & $70.5 \mathrm{~d}$ & $1.43 \mathrm{c}$ & $1.04 \mathrm{c}$ & $2.76 \mathrm{a}$ & $3.02 \mathrm{a}$ \\
\hline M2 x F2-A & 8 & $61.0 \mathrm{c}$ & $75.0 \mathrm{c}$ & $1.47 \mathrm{c}$ & $1.28 \mathrm{~b}$ & $3.20 \mathrm{a}$ & $2.46 \mathrm{a}$ \\
\hline M2 x F3-A & 9 & $60.5 \mathrm{c}$ & $77.0 \mathrm{~b}$ & $1.45 \mathrm{c}$ & $1.29 \mathrm{~b}$ & $2.82 \mathrm{a}$ & $2.32 \mathrm{a}$ \\
\hline M2 x F4-A & 10 & $60.5 \mathrm{c}$ & $73.0 \mathrm{c}$ & $1.57 \mathrm{~b}$ & $1.38 \mathrm{a}$ & $4.21 \mathrm{a}$ & $1.93 \mathrm{~b}$ \\
\hline M2 x F5-A & 11 & $66.5 \mathrm{a}$ & $74.0 \mathrm{c}$ & $1.05 \mathrm{~d}$ & $0.85 \mathrm{~d}$ & $1.45 \mathrm{~b}$ & $1.04 \mathrm{~b}$ \\
\hline M2 x F6-A & 12 & $63.0 \mathrm{~b}$ & $82.0 \mathrm{a}$ & $1.1 \mathrm{~d}$ & $1.16 \mathrm{~b}$ & $1.37 \mathrm{~b}$ & $0.92 \mathrm{~b}$ \\
\hline M3 x F1-A & 13 & $60.5 \mathrm{c}$ & $70.0 \mathrm{~d}$ & $1.70 \mathrm{~b}$ & $1.41 \mathrm{a}$ & $2.84 \mathrm{a}$ & $2.74 \mathrm{a}$ \\
\hline M3 x F2-A & 14 & $60.5 \mathrm{c}$ & $71.5 \mathrm{~d}$ & $1.89 \mathrm{a}$ & $1.58 \mathrm{a}$ & $3.61 \mathrm{a}$ & $2.19 \mathrm{a}$ \\
\hline M3 x F3-A & 15 & $60.5 \mathrm{c}$ & $74.0 \mathrm{c}$ & $1.90 \mathrm{a}$ & $1.51 \mathrm{a}$ & $4.27 \mathrm{a}$ & $2.86 \mathrm{a}$ \\
\hline M3 x F4-A & 16 & $60.0 \mathrm{c}$ & $77.0 \mathrm{~b}$ & $1.90 \mathrm{a}$ & $1.58 \mathrm{a}$ & $3.62 \mathrm{a}$ & $0.75 \mathrm{~b}$ \\
\hline M3 x F5-A & 17 & $66.5 \mathrm{a}$ & $80.0 \mathrm{a}$ & $1.61 \mathrm{~b}$ & $1.28 \mathrm{~b}$ & $1.84 \mathrm{~b}$ & $1.03 \mathrm{~b}$ \\
\hline M3 x F6-A & 18 & $63.0 \mathrm{~b}$ & $79.5 \mathrm{a}$ & $1.51 \mathrm{c}$ & $1.31 \mathrm{~b}$ & $3.54 \mathrm{a}$ & $1.23 \mathrm{~b}$ \\
\hline M4 x F1-A & 19 & $60.5 \mathrm{c}$ & $71.0 \mathrm{~d}$ & $1.53 \mathrm{~b}$ & $1.35 \mathrm{a}$ & $3.29 \mathrm{a}$ & $3.09 \mathrm{a}$ \\
\hline M4 x F2-A & 20 & $59.5 \mathrm{c}$ & $73.0 \mathrm{c}$ & $1.68 \mathrm{~b}$ & $1.48 \mathrm{a}$ & $4.11 \mathrm{a}$ & $3.30 \mathrm{a}$ \\
\hline M4 x F3-A & 21 & $58.0 \mathrm{c}$ & $73.5 \mathrm{c}$ & $1.63 \mathrm{~b}$ & $1.49 \mathrm{a}$ & $3.99 \mathrm{a}$ & $2.46 \mathrm{a}$ \\
\hline M4 x F4-A & 22 & $58.5 \mathrm{c}$ & $69.0 \mathrm{~d}$ & $1.70 \mathrm{~b}$ & $1.51 \mathrm{a}$ & $5.01 \mathrm{a}$ & $2.97 \mathrm{a}$ \\
\hline M4 x F5-A & 23 & $66.0 \mathrm{a}$ & $64.5 \mathrm{e}$ & $1.48 \mathrm{c}$ & $1.45 \mathrm{a}$ & $3.62 \mathrm{a}$ & $2.85 \mathrm{a}$ \\
\hline M4 x F6-A & 24 & $62.5 \mathrm{~b}$ & $82.0 \mathrm{a}$ & $1.31 \mathrm{c}$ & $1.01 \mathrm{c}$ & $3.84 \mathrm{a}$ & $2.01 \mathrm{~b}$ \\
\hline M5 x F1-A & 25 & $57.0 \mathrm{~d}$ & $72.0 \mathrm{c}$ & $1.60 \mathrm{~b}$ & $1.52 \mathrm{a}$ & $1.11 \mathrm{~b}$ & $3.14 \mathrm{a}$ \\
\hline M5 x F2-A & 26 & $59.5 \mathrm{c}$ & $72.0 \mathrm{c}$ & $1.43 \mathrm{c}$ & $1.43 \mathrm{a}$ & $1.93 \mathrm{~b}$ & $3.56 \mathrm{a}$ \\
\hline M5 x F3-A & 27 & $59.0 \mathrm{c}$ & $70.0 \mathrm{~d}$ & $1.57 \mathrm{~b}$ & $1.43 \mathrm{a}$ & $1.86 \mathrm{~b}$ & $2.24 \mathrm{a}$ \\
\hline M5 x F4-A & 28 & $58.5 \mathrm{c}$ & $72.0 \mathrm{c}$ & $1.65 \mathrm{~b}$ & $1.55 \mathrm{a}$ & $3.15 \mathrm{a}$ & $1.86 \mathrm{~b}$ \\
\hline M5 x F5-A & 29 & $62.0 \mathrm{~b}$ & $77.0 \mathrm{~b}$ & $1.44 \mathrm{c}$ & $1.29 \mathrm{~b}$ & $3.26 \mathrm{a}$ & $1.39 \mathrm{~b}$ \\
\hline M5 x F6-A & 30 & $62.0 \mathrm{~b}$ & $62.5 \mathrm{e}$ & $1.24 \mathrm{~d}$ & $1.45 \mathrm{a}$ & $2.99 \mathrm{a}$ & $2.00 \mathrm{~b}$ \\
\hline M6 x F1-A & 31 & $55.0 \mathrm{~d}$ & $70.5 \mathrm{~d}$ & $1.55 \mathrm{~b}$ & $1.52 \mathrm{a}$ & $1.23 \mathrm{~b}$ & $2.88 \mathrm{a}$ \\
\hline M6 x F2-A & 32 & $59.0 \mathrm{c}$ & $72.5 \mathrm{c}$ & $1.41 \mathrm{c}$ & $1.16 \mathrm{~b}$ & $2.02 \mathrm{~b}$ & $1.62 \mathrm{~b}$ \\
\hline M6 x F3-A & 33 & $54.5 \mathrm{~d}$ & $70.0 \mathrm{~d}$ & $1.53 \mathrm{~b}$ & $1.45 \mathrm{a}$ & $1.71 \mathrm{~b}$ & $1.57 \mathrm{~b}$ \\
\hline M6 x F4-A & 34 & $54.5 \mathrm{~d}$ & $70.0 \mathrm{~d}$ & $1.57 \mathrm{~b}$ & $1.51 \mathrm{a}$ & $1.49 \mathrm{~b}$ & $2.21 \mathrm{a}$ \\
\hline M6 x F5-A & 35 & $58.5 \mathrm{c}$ & $78.0 \mathrm{~b}$ & $1.22 \mathrm{~d}$ & $1.26 \mathrm{~b}$ & $1.13 \mathrm{~b}$ & $0.86 \mathrm{~b}$ \\
\hline M6 x F6-A & 36 & $55.0 \mathrm{~d}$ & $72.0 \mathrm{c}$ & $1.39 \mathrm{c}$ & $1.23 \mathrm{~b}$ & $2.07 \mathrm{~b}$ & $0.70 \mathrm{~b}$ \\
\hline Mean & & 60.31 & 73.54 & 1.52 & 1.35 & 2.75 & 2.01 \\
\hline
\end{tabular}

A significant interaction between GCA x E for grain yield was also represented in figure 1 (page 16). The M4 line stands out for presenting the highest GCA estimates among the restorers at both sites, contributing to an increased grain yield for the hybrids 19, 20, 21, 22, 23, and 24. Male-sterile lines F2-A and F3-A obtained the highest GCA estimates considering the two sites, where most hybrids $(3,8,9,14,15,20$, and 21$)$ generated by using these lines as female parents obtained high means.

\section{Potential of grain sorghum hybrids}

SCA estimates for days to flowering and plant height are shown in figure 2 (page 18). Regarding days to flowering, the hybrids 4, 7, 14, 22, 33, and 36 presented negative estimates, besides the lowest means (table 4 ) for this trait at both sites. Furthermore, it is interesting to highlight the hybrids 2, 20,21, 25, 29, and 35, which obtained low SCA estimates at Sinop, representative site for the sorghum crop. 

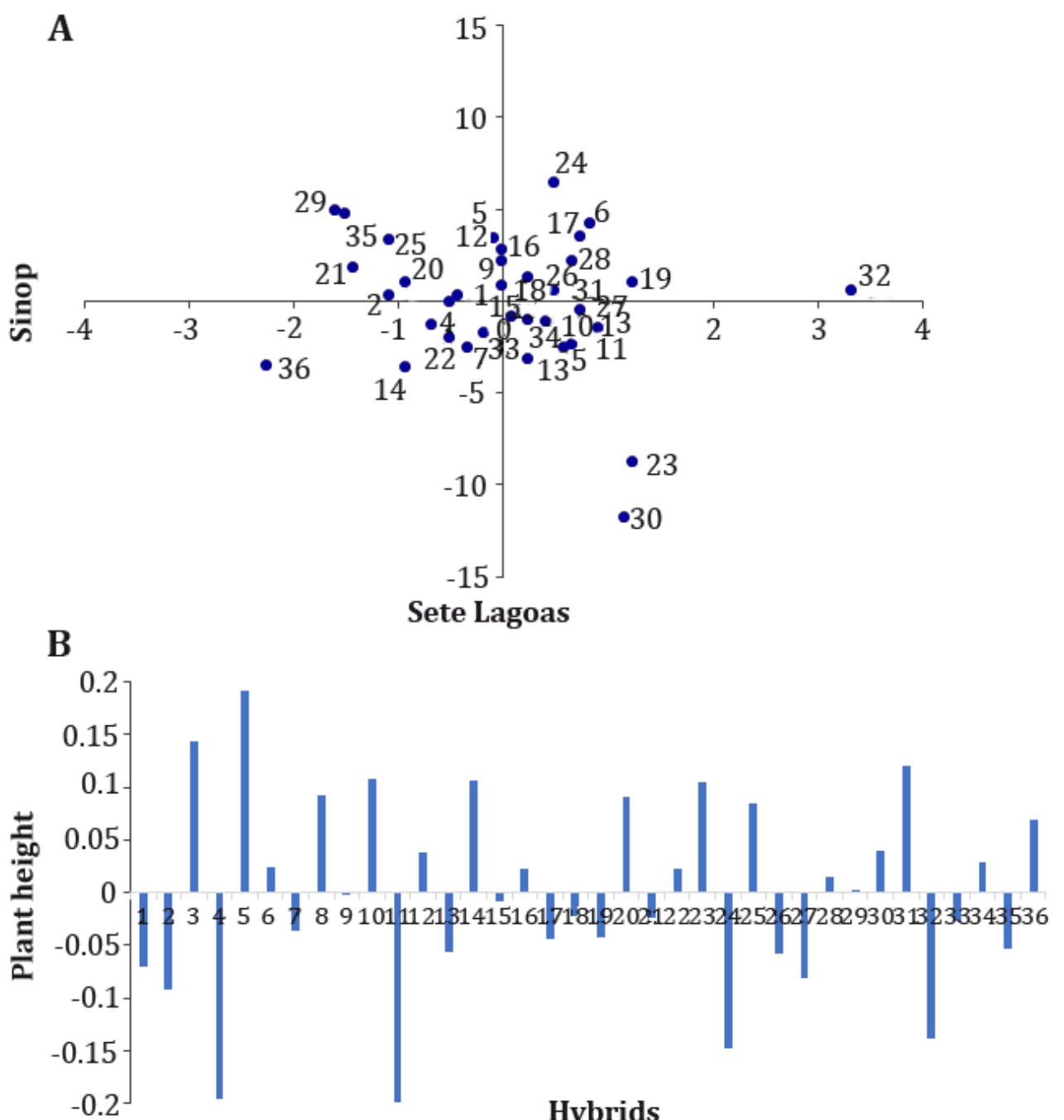

Figure 2. Estimates of specific combining ability (SCA) for days to flowering (A) and plant height (B) evaluated in 12 grain sorghum lines grown at Sinop-MT and Sete Lagoas-MG.

Figura 2. Estimaciones de capacidad específica de combinación (CEC) para los caracteres días a floración (A) y altura de planta (B) evaluados en 12 líneas de sorgo de grano cultivados en Sinop-MT y Sete Lagoas-MG.

Regarding plant height, it was showed the SCA estimates considering the mean of the two sites since the SCA x E interaction for this trait was not significant. The hybrids 1, 2, 4, $7,11,17,18,19,21,24,26,27,32,33$, and 35 obtained the lowest estimates considering the two sites. Furthermore, hybrids 1, 2, 4, 7, 32, 33, and 35 stood out for obtaining greater earliness at both sites.

\section{Discussion}

Impact of combining ability on the future of the grain sorghum breeding

Significant effect for hybrids for all traits reveals the existence of genetic variability among the genotypes. In cases where GCA is significant, it can be inferred that, at least, one parent differs from the others regarding the concentration of favorable alleles (6). The significance of GCA I for plant height and GCA II for days to flowering and plant height indicates the existence of parents contributing with a higher number of favorable alleles for these traits 
transmitted to offspring (17). On the other hand, significant SCA effects evidenced that there are deviations from hybrids behavior concerning what was expected based on the GCA of parents (5). This allows inferring that, for days to flowering and grain yield, whose SCA estimates were not significant, the hybrid populations behaved as expected based on the GCA of parents.

Flowering is highly correlated with the crop cycle and is an essential measure for the off-season sorghum, since the flowering is a susceptible stage to water stress, and the sooner the plant to complete its cycle in off-season crops, the better chance it will have to escape the dry period (12). Furthermore (20) reported that plant height between 1.0 and $1.5 \mathrm{~m}$ is desirable for facilitating the harvesting with adapted soybean or maize harvesters. These characteristics are important to consolidate the grain sorghum cultivation in the off-season in the Brazilian Cerrado. For this reason, negative GCA and SCA estimates for days to flowering and plant height are desirable, aiming at reducing the mean values of these traits in sorghum genotypes.

The superiority of GCA effects regarding SCA reveals that additive effects are predominant in controlling these traits. Additive gene effects are cumulative over generations and are the main sources of genetic variation exploited by most breeding programs (8), since it is responsible for setting the characteristics of interest. Menezes et al. (2014), Menezes et al. (2015) and Mohammed et al. (2015) also found predominance of additive gene effects in controlling these traits. However, Premalatha et al. (2006) reported that both additive and non-additive effects govern the inheritance of agronomic traits in sorghum.

The presence of significant G x E interaction can be attributed to predictable factors, such as soil, pests and disease management, supplementary irrigation, base fertilization, among others, such as rainfall, temperature, relative air humidity, and solar radiation over the crop cycle at these sites.

The traits here studied are governed by many small-effect genes on the phenotype and highly influenced by the environment. The CV values show experimental accuracy and are inferior to other studies with sorghum genotypes $(10,11,12,20)$.

Currently, grain sorghum breeding programs seek to develop hybrids with earliness, shorter height, and high grain yield $(12,14)$. These characteristics are desirable to consolidate off-season growing of this crop in Brazilian Cerrado. Thus, the presence of significant GCA $x$ $\mathrm{E}$ interaction for some traits indicates that the additive allele effect donated by the parents is changed depending on the environment.

Grain sorghum breeding should be done individually in each line group, in which male-sterile lines breeding is performed in their isogenic lines (B lines) and, subsequently, cytoplasmic-genetic male sterility is introduced. Hence, the identification of parents from each Group ( $\mathrm{R}$ and $\mathrm{A}$ ) that donate alleles exerting desirable effects at both sites is a promising strategy for developing future hybrids with broad adaptability for these traits.

In this study, lines from each group contributing to the desired phenotype in the respective hybrids generated were identified. It was found that favorable alleles for each trait are contained in different parents. No parent is a good donor of favorable alleles for all traits at the two sites. A strategy to be adopted to obtain hybrids simultaneously gathering earliness, plant height suitable for harvesting, and high yield is the gene pyramiding, which allows the concentration of a set of genes in a single individual.

Thus, this study presents a proposal for the next steps of the grain sorghum breeding program, aiming at pyramiding of favorable genes for all traits evaluated in lines of each group (figure 3, page 20). To improve the R lines, it is proposed to cross M2 (good donor for shorter height at both sites) x M5 (good donor for earliness at both sites). The hybrid resulting from this cross can be crossed with the M4 line (good donor for high grain yield at both sites). From this, a population with favorable alleles will be obtained for all traits, in which the selection of the most promising lines must be carried out. 


\section{Breeding - $\mathrm{R}$}



Breeding - A (by means of B lines)

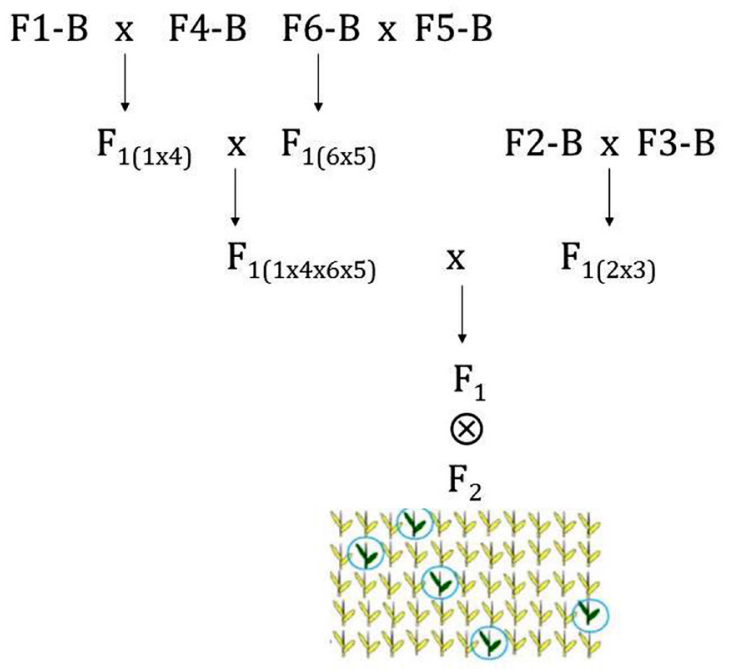

Figure 3. Breeding proposal for obtaining restorative (R) and male-sterile (A) lines gathering earliness, shorter height and high grain yield for the two sites evaluated.

Figura 3. Propuesta de mejoramiento para obtención de líneas restauradoras (R) y machos-estériles (A) reuniendo precocidad, menor altura de planta y alta productividad de granos para los locales evaluados.

Owing to the presence of cytoplasmic-genetic male sterility in the A lines, the cross among male-sterile lines (A) is unfeasible. Hence, the A lines breeding should occur through their maintainers, B isogenic lines, which has fertile cytoplasm. In this case, complex crosses should be performed to gather favorable alleles for all traits in a single population. Maintainer lines (B) crosses in pairs, based on selected A lines, should be performed. These crosses can be carried out manually by emasculating one of the lines and using the pollen from the other.

Therefore, we proposed that the hybrid generated by the cross among the maintaining lines F1-B x F4-B (high earliness) should be crossed with the hybrid derived from maintainers F6-B x F5-B (shorter height). In turn, the new hybrid should be crossed with the hybrid generated by F2-B x F3-B (high grain yield). Thus, there will be the transmission of favorable genes, which are dispersed among the parents, to a single population in which the selection should be carried out. At last, the B lines selected in this population would be crossed with a cytoplasmic male sterile source and then, by using backcrossing, to obtain new pairs of $A$ and $B$ lines.

\section{Conclusions}

The findings provided by the combining ability analysis allowed the identification of promising lines to be used as parents in a grain sorghum breeding program. As the traits of interest are found in different lines, complex crosses should be performed to gather favorable alleles for the traits evaluated in new restorative and male-sterile lines.

For improving R lines, we proposed the crossing M2 x M5 (donors for shorter height and earliness, respectively). The hybrid resulting from this cross must then be crossed with M4, which is a good donor for high grain yield. Another breeding strategy should be carried out on the maintainer lines, in which complex crosses involving the hybrids resulting from F1-B x F4-B, F6-B x F5-B, and F2-B x F3-B should be carried out in order to transfer favorable genes dispersed among the parents to a single population in which the selection should be carried out. 
Regarding hybrids, we identified that 7, 9, 19, and 22 are the most suitable hybrids for growing in the evaluated environments since they have earliness, adequate height to harvesting, and high grain yield, as well as high phenotypic stability for these traits.

Taking into account that this study assessed 36 grain sorghum hybrids at two sites in one crop season, we understand that the findings are accurate for the traits flowering and plant height, but may not be ideal for yield assessment, which is one of the possible reasons for the high data variability verified for this trait. In this sense, further studies assessing more hybrids and environments (sites and crop seasons) should be carried out to support our findings, especially regarding grain yield.

\section{REFERENCES}

1. Adams, C. B.; Erickson, J. E. 2017. Yield enhancement by short-term imposition of severe water deficit in the vegetative growth stage of grain sorghum. J Agron Crop Sci. 203: 309-314.

2. Assefa, Y.; Staggenborg, S. A.; Prasad, V. P. V. 2010. Grain sorghum water requirement and responses to drought stress: A Review. Crop Manag. 9.

3. Boyles, R. E.; Pfiefferc, B. K.; Coopera, E. A.; Zielinskid, K. J.; Myersa, M. T.; Rooneyc, W. L.; Kresovich, S. 2017. Quantitative trait loci mapping of agronomic and yield traits in two grain sorghum biparental families. Crop Sci. 57: 2443-2456.

4. Cruz, C. D. 2013. GENES - a software package for analysis in experimental statistics and quantitative genetics. Acta Sci. Agron. 35: 271-276.

5. Cruz, C. D.; Vencovsky, R. 1989. Comparação de alguns métodos de análise dialélica. Rev Bras Gen. 12: $425-438$.

6. Cruz, C. D.; Regazzi, A. J.; Carneiro, P. C. S. 2012. Modelos biométricos aplicados ao melhoramento genético. $4^{\text {th }}$ ed. Viçosa: UFV.

7. Griffing, B. A. 1956. Concept of general and specific combining ability in relation to diallel cross systems. Aust. J. Biol. Sci. 9: 463-493.

8. Isik, F.; Li, B.; Frampton, J. 2003. Estimates of additive, dominance and epistatic genetic variances from a clonally replicated test of loblolly pine. Forest Sci. 49: 77-88.

9. Kenga, R.; Alabi, S. O.; Gupta, S. C. 2004. Combining ability studies in tropical sorghum [Sorghum bicolor (L.) Moench]. Field Crops Res. 88: 251-260.

10. Kumar, A. A.; Reddy, B. V. S.; Sharma, H. C.; Hash, C. T.; Rao, P. S.; Ramaiah, B.; Reddy, O. S. 2011. Recent advances in sorghum genetic enhancement research at ICRISAT. Am J Plant Sci. 2: 589-600.

11. Menezes, C. B.; Carvalho Junior, G. A.; Silva, L. A.; Bernardino, K. A.; Souza, V. F.; Tardin, F. D.; Schaffer, R. E. 2014. Combining ability of grain sorghum lines selected for aluminum tolerance. Crop Breed. Appl. Biotechnol. 14: 42-48.

12. Menezes, C. B.; Santos, C. V.; Júlio, M. P. M.; Silva, K. J.; Saldanha, D. C.; Tuma e Silva, C. H.; Tardin, F. D.; Rodrigues, J. A. S. 2015. Capacidade combinatória de linhagens de sorgo granífero cultivados em segunda safra. Sete Lagoas: Embrapa Milho e Sorgo.

13. Mohammed, R.; Are, A. K.; Bhavanasi, R.; Munghati, R. S.; Kavi Kishor, P. B.; Sharma, H. C. 2015. Quantitative genetic analysis of agronomic and morphological traits in sorghum, Sorghum bicolor. Front. Plant Sci. 6: PMC4630571.

14. Oliveira de Souza, N.; Silva Alves, R.; Teodoro, P. E.; Silva, L. A.; Tardin , F. D.; Baldoni Tardin, A.; Vilela de Resende, M. D.; Lopes Bhering, L. 2019. Single- and multiple-trait BLUP in genetic selection of parents and hybrids of grain sorghum. Revista de la Facultad de Ciencias Agrarias. Universidad Nacional de Cuyo. Mendoza. Argentina. 51(2): 1-12.

15. Paterson, A. H.; Bowers, J. E.; Bruggmann, R. 2009. The Sorghum bicolor genome and the diversification of grasses. Nature. 457: 551-556.

16. Premalatha, N.; Kumaravadivel, N.; Veerabadhiran, P. 2006. Heterosis and combining ability for grain yield and its components in sorghum [Sorghum bicolor (L.) Moench]. Indian J. Genet. 66: 123-126.

17. Ramalho, M. A. P.; Ferreira, D. F.; Oliveira, A. C. 2012. Experimentação em genética e melhoramento de plantas. Lavras: UFLA.

18. Schlegel, A. J.; Lamm, F. R.; Assefa, Y.; Stone, L. R. 2018. Dryland corn and grain sorghum yield response to available soil water at planting. Agron J. 110: 236-245.

19. Scott, A. J.; Knott, M. 1974. A cluster analysis method for grouping means in the analysis of variance. Biometrics. 30: 507-512.

20. Tardin, F. D.; Almeida Filho, J. E.; Oliveira, C. M.; Leite, C. E. P.; Menezes, C. B.; Magalhães, P. C.; Rodrigues, J. A. S.; Schaffert, R. E. 2013. Avaliação agronômica de híbridos de sorgo granífero cultivados sob irrigação e estresse hídrico. Rev Bras Milho Sorgo. 12: 102-117.

\section{ACKNOWLEDGEMENTS}

This work was financed in part by the Coordenação de Aperfeiçoamento de Pessoal de Nível Superior - Brasil (CAPES) - Finance Code 001. The authors also thank Embrapa and CNPq (National Council for Scientific and Technological Development) for financial support. 